\title{
ОНЛАЙН-ШКОЛА ДИАБЕТА В УСЛОВИЯХ ПАНДЕМИИ
}

\author{
И.Ю. Черняк', Е.Л. Сиделева', И.А. Махрова', А.Е. Семизаров², Т.И. Семизарова² \\ 'ГБУЗ «Детская краевая клиническая больница» МЗ КК, г. Краснодар \\ ${ }^{2}$ Краснодарское региональное отделение Общероссийской общественной организачии \\ инвалидов «Российская диабетическая ассочиация», г. Краснодар
}

В настоящее время в мире насчитывается более 300 млн больных сахарным диабетом (СД). В большинстве стран, включая Россию, регистрируется рост заболеваемости СД 1 типа (СД1) в детском возрасте, особенно в развивающихся странах и странах с высоким экономическим развитием. В Краснодарском крае на 01.01.2021 г. зарегистрировано 1993 ребенка с СД1. Обучение пациентов с СД1 является необходимым условием успешного лечения, адекватного гликемического контроля и профилактики осложнений.

ЦЕЛЬ: проанализировать результаты работы онлайн-школы диабета для детей

РЕзУЛЬтАТЫ: Для обучения пациентов с СД1 в Краснодарском крае на базе ГБУЗ «Детская краевая клиническая больница» министерства здравоохранения Краснодарского края (ГБУз ДККБ МЗ КК) с 2008 года работает школа диабета, которая с 2014 г. функционирует как структурное подразделение.

В условиях возникновения новой коронавирусной инфекции пациенты с хроническими заболеваниями, в том числе с СД1, рекомендуется ограничение контактов, так как они входят в группу риска инфицирования.

Пациенты и их семьи, находясь в условиях вынужденной изоляции, испытывают психологический дискомфорт. Эмоциональные трудности семей можно рассмотреть, как реакцию на стрессовую ситуацию, связанную с заболеванием ребенка. Эти состояния усугубляются недостатком знаний и навыков, что приводит к снижению приверженности к лечению, проведению самоконтроля, снижению мотивации пациента к управлению СД1. Долгосрочное течение пандемии привело к ограничению очного взаимодействия и возникновения необходимости перехода на дистанционное обучение.

Проект «Медико-психологические обучающие онлайн-вебинары в «Школе для пациентов с сахарным диабетом» для детей-инвалидов с СД 1 и их родителей во время и после пандемии», разработанный Краснодарским региональным отделением общероссийской общественной организации инвалидов «Российская диабетическая ассоциация» (КРООООИ «РДА») стал победителем конкурса Фонда Президентских грантов в 2021 году. Проект направлен на достижение и поддержание компенсации сахарного диабета путем внедрения новых форм обучения. В рамках проекта планируется проведение 12 онлайн-вебинаров по управлению СД 1, поддержанию эмоционального равновесия в семье. Занятия проводятся врачами детскими эндокринологами и медицинским психологом ГБУЗ ДККБ МЗ КК. В качестве методической основы обучающих программ используются: «Алгоритмы специализированной медицинской помощи больным сахарным диабетом») под. ред. И.И. Дедова, М.В. Шестаковой. М., 2019, клинические рекомендации «Сахарный диабет 1 типа у детей. 2019 г.».

Трансляция онлайн-вебинаров осуществляется в прямом эфире на Ютуб-канале КРООООИ «РДА». Преимущество такой формы обучения: подключение неограниченного количества участников из любых регионов, доступность для людей разного социального статуса и уровня благосостояния, возможность просмотра материала неограниченного количества раз по мере необходимости. В ходе прямой трансляции участники вебинаров имеют возможность задать вопросы ведущему и получить ответ.

В ходе обучения в «Школе для пациентов с сахарным диабетом» в формате онлайн дети с инсулинозависимым сахарным диабетом получат необходимые знания о инсулинотерапии, технике инъекций, правилах подбора доз инсулина, действиях при жизнеугрожающих ситуациях. Это позволит уменьшить число внеплановых госпитализаций в стационар. 


\section{СБОРНИК ТЕЗИСОВ}

XVII Российская научно-практическая конференция детских эндокринологов «Достижения науки в практику детского эндокринолога»

Занятия с психологом установит партнерские отношения «Сахарный диабет+ребенок+родители», с учетом особенностей института семьи.

Проект востребован и получил положительные отзывы семей, воспитывающих детей Сд1. Во время трансляции подключение участников составляло более 200 человек.

Выводы. Таким образом, онлайн-обучение позволяет использовать новые инновационные методики в комплексном лечении пациентов с СД 1 и проведение эффективной психологической коррекции.

Важным аспектом процесса обучения является создание условий для участников, в которых они смогут принимать решения и планировать изменения в своей жизни и управлении СД1. 